\title{
EVALUASI PELAYANAN PREVENTION OF MOTHER TO CHILD TRANSMISSION (PMTCT) OF HIV PADA ANTE NATAL CARE (ANC) DI RUMAH SAKIT UMUM ADAM MALIK MEDAN
}

\author{
EVALUATION OF PREVENTION OF MOTHER TO CHILD \\ TRANSMISSION (PMTCT) OF HIV SERVICES AT ANTE NATAL \\ CARE (ANC) AT ADAM MALIK GENERAL HOSPITAL, MEDAN
}

\author{
Lolita Nugraeny ${ }^{*}$, Sumiatik ${ }^{2}$
}

${ }^{1,2}$ Fakultas Kesehatan, Universitas Haji Sumatera Utara, Jalan RS Haji Medan Estate, 20237, Sumatera Utara

*Koresponding Penulis: ${ }^{1 *}$ Lolitanugraeny@gmail.com, ${ }^{2}$ Sumiatik46@gmail.com

\begin{abstract}
Abstrak
Prevention Of Mother To Child Transmission Of HIV (PMTCT) adalah upaya pengendalian HIV-AIDS dan Infeksi Menular Seksual di Indonesia serta Program Kesehatan Ibu dan Anak. Tujuan penelitian untuk mengevaluasi pelaksanaan pelayanan PMTCT pada Antenatal Care di RSUP Adam Malik Medan. Penelitian ini jenis deskriptif dengan menggunakan pendekatan kualitatif. Metode pengumpulan data menggunakan wawancara mendalam, teknik analisa data content analysis. Hasil penelitian menunjukan pelaksanaan pelayanan PMTCT sudah baik, antara lain dari standar input, standar proses sudah berjalan dengan baik namun sosialisasi program terhadap pasien perlu ditingkatkan, terjadi peningkatan pada standar output pelaksanaan. Diharapkan pelayanan PMTCT meningkatkan sosialisasi program.
\end{abstract}

\section{Kata Kunci : HIV, PMTCT}

Abstract
Prevention Of Mother To Child Transmission Of HIV (PMTCT) is an effort to control HIV-AIDS and sexually transmitted infections in Indonesia as well as the Maternal and Child Health Program. The research objective was to evaluate the implementation of PMTCT services at Antenatal Care at Adam Malik Hospital, Medan. This type of research is descriptive using a qualitative approach. Data collection methods using in-depth interviews, content analysis data analysis techniques. The results showed that the implementation of PMTCT services was good, among others, from the standard input, the standard process had been going well, but the program socialization for patients needed to be improved, there was an increase in the implementation output standard. It is hoped that PMTCT services will increase program socialization

\section{Keyword $\quad$ : HIV, PMTCT}

\section{PENDAHULUAN}

Pencegahan Penularan HIV dari Ibu ke Anak (PPIA) atau Prevention of Mother-to Child Transmission (PMTCT) merupakan bagian dari upaya pengendalian HIV-AIDS dan Infeksi 
Journal of Healthcare Technology and Medicine Vol. 6 No. 2 Oktober 2020

Universitas Ubudiyah Indonesia

e-ISSN : 2615-109X

Menular Seksual (IMS) di Indonesia serta Program Kesehatan Ibu dan Anak (KIA). Indonesia adalah salah satu negara di Asia dengan epidemi HIV/AIDS yang berkembang paling cepat (UNAIDS, 2008) dan merupakan negara dengan tingkat epidemi HIV terkonsentrasi, karena terdapat beberapa daerah dengan prevalensi HIV lebih dari 5\% pada subpopulasi tertentu, dan prevalensi HIV tinggi pada populasi umum 15-49 tahun terjadi di Provinsi Papua dan Papua Barat (2,4\%) (Kemenkes RI, 2013).

Data menunjukkan 21.103 ibu hamil yang menjalani tes HIV, 534 dan (2,5\%) di antaranya positif terinfeksi HIV. Angka prevalensi dan penularan HIV dari ibu ke bayi masih terbatas, jumlah ibu hamil yang terinfeksi HIV cenderung meningkat. Prevalensi HIV pada ibu hamil diproyeksikan meningkat dari 0,38\% pada tahun 2012 menjadi 0,49\% pada tahun 2016, dan jumlah ibu hamil HIV positif yang memerlukan layanan PPIA juga akan meningkat dari 13.189 orang pada tahun 2012 menjadi 16.191 orang pada tahun 2016 . Provinsi Sumatera Utara menduduki peringkat ketiga untuk jumlah kasus HIV yaitu sebanyak 5.935 kasus (Kemenkes RI, 2012).

Tingginya jumlah ibu hamil yang didiagnosa positif HIV juga akan meningkatkan resiko penularan HIV terhadap bayi yang dikandungnya. Penularan HIV dari ibu ke bayi bisa terjadi pada saat selama kehamilan, selama proses melahirkan dan pada saat menyusui. Faktor yang mempengaruhi penularan HIV dari ibu ke bayi adalah jumlah virus, jumlah sel CD4 yang rendah, status gizi ibu selama hamil yang tidak tercukupi, penyakit infeksi selama hamil, gangguan payudara, bayi yang lahir prematur, luka pada mulut bayi dan termasuk factor obstetric yaitu lamanya proses persalinan, dan tindakan episiotomy selama persalinan. dan salah satu upaya yang telah terbukti mampu mencegah penularan HIV dari ibu kebaya adalah Pencegahan Penularan HIV dari Ibu ke Anak (PPIA) (Kemenkes RI, 2012).

Pelaksanaan program PPIA masih belum bisa dilaksanakan dengan baik, hal ini seperti yang dilihat dari hasil penelitian Desi Zulaikha tahun 2013. Faktor yang menyebabkan terhambatnya pelaksanaan PPIA dan salah satunya adalah dengan banyaknya jumlah pasien penderita HIV yang berobat, waku pemeriksaan yang lama serta pasien yang tidak terbuka dalam menjawab pertanyaan yang diberikan petugas kesehatan.

Hasil dari penelitian yang dilakukan oleh Syarah Vonny di Rumah Sakit Haji Medan tahun 2013, bahwa masih banyak Bidan KIA yang bertugas di pelayanan PMTCT tetapi kurang paham dengan PMTC serta tidak melaksanakan pelayanan PMTCT sesuai dengan buku pedoman.Berdasarkan dari beberapa penelitian yang telah dilakukan, maka dilakukan 
Journal of Healthcare Technology and Medicine Vol. 6 No. 2 Oktober 2020

Universitas Ubudiyah Indonesia

e-ISSN : 2615-109X

penelitian tentang evaluasi pelaksanaan pelayanan PPIA di Kota Medan khususnya di Rumah Sakit Umum Pusat H. Adam Malik Medan.

\section{METODE PENELITIAN}

Metode pengumpulan data menggunakan wawancara mendalam dan observasi. Informan dalam penelitian ini adalah petugas bidan KIA, perawat, dokter dan ibu hamil yang positif HIV. Pengumpulan data yang dilakukan adalah dengan data primer dan data sekunder. Data primer diperoleh dari wawancara mendalam (indepth interview) yang dilakukan secara langsung terhadap informan yang berkaitan dengan program PMTCT serta ibu hamil yang memeriksakan kehamilannya di Poliklinik PMTCT dan didiagnosa positif HIV.

Observasi dilakukan untuk mengamati dan melihat bagaimana kondisi ataupun keadaan informan secara lebih mendalam lagi pada saat melakukan penelitian. Informan dalam penelitian ini ditentukan secara purposive. Teknik Analisa data content analysis (reduksi data, penyajian data, dan penarikan kesimpulan).

\section{HASIL DAN PEMBAHASAN}

Umur informan bervariasi antara 23-52 tahun. Dimana informan berjumlah 12 orang 8 diantaranya adalah pasien ibu hamil yang positife HIV dan 4 diantaranya adalah petugas kesehatan. Karakteristik yang menjadi informan dalam penelitian ini adalah 2 orang berjenis kelamin laki-laki dan 10 orang berjenis kelamin perempuan. Informan dalam penelitian ini memiliki latar belakang pendidikan yang berbeda-beda. Informan yang dari pasien itu sendiri 1 orang latar belakang pendidikannya SD, 4 orang SMP dan 3 orang berlatang belakang SMA. Informan yang bekerja sebagai petugas kesehatan 1 orang latar belakang pendidikannya D-IV Bidan Pendidik, 1 orang S1 Keperawatan dan 2 orang Dokter Spesialis Obgyn. Lama tugas setiap informan bervariasi yaitu 1 orang mengatakan sudah bekerja selama 20 tahun, 1 orang 21 tahun, 1 orang 22 tahun dan 1 orang yang lain 24 tahun.

\section{Standar Input}

Berdasarkan jawaban yang didapatkan dari informan yang bertuga di klinik fusyansus dikatakan bahwa jumlah petugas kesehatan yang menangani ataupun yang memberikan asuhan kepada ibu hamil yang positif HIV adalah satu orang dan petugas kesehatan yang lain terdapat di ruangan Poli Ibu Hamil. Dimana di Poli Ibu Hamil terdapat 1 orang Bidan dan 
Journal of Healthcare Technology and Medicine Vol. 6 No. 2 Oktober 2020

Universitas Ubudiyah Indonesia

e-ISSN : 2615-109X

Dokter Obgyn. Jawaban informan tersebut senada dengan yang disampaikan oleh petugas kesehatan yang ada di Poli Ibu Hamil. Dimana ketiga informan yang bertugas di Poli Ibu Hamil mengatakan terdapat 3 orang petugas kesehatan yang memberikan pelayanan PMTCT pada ibu hamil diantaranya adalah 1 orang Bidan dan 2 Dokter Obgyn.

Jawaban dari pertanyaan ini ditanyakan langsung kepada informan yang berlatar belakang petugas kesehatan. Jumlah informan adalah sebanayak 4 orang. Semua informan memberikan jawaban yang sama dimana mereka mengatakan bahwa semua peralatan yang digunakan dalam memeberikan pelayanan PMTCT sudah memenuhi standard dan ketentuan yang ditetapkan untuk peralatan di Rumah Sakit Tipe A. Dari hasil yang didapatkan berdasarkan jawaban 4 orang informan yang memberikan jawaban yang sama yaitu mereka mengatakan fasilitas yang ada dalam pelayanan PMTCT seperti laboratorium sudah ada dan memenuhi standar yang berlaku.

Berdasarkan wawancara yang dilakukan ke 4 informan memberikan jawban yang kurang lebih sama. Dimana jawaban informan yang pertama adalah bahwa beliau mengatakan dia kurang mengerti tentang apa itu kebijakan standar, tetapi untuk semua prosedur yang akan dilakukan memang sudah ada di tetapkan SK, Protap dan SOP yang harus diikuti oleh semua petugas. Informan yang kedua juga mengatakan hal yang senada bahwa semua tindakan yang akan diberikan terhadap pasien harus mengikuti SOP yang sudah ditetapkan oleh pihak Rumah Sakit itu sendiri. Jawaban yang sama juga diberikan oleh informan ketiga dan keempat. Mereka menuturkan bahwa apapun tindakan yang akan dilakukan terhadap pasien haruslah mengikuti langkah-langkah ataupun SOP yang berlaku dan yang sudah ditetapkan oleh pihak Rumah Sakit.

Dari semua jawaban informan peneliti menyimpulkan bahwa segala sesuatu tindakan yang dilakukan sudah ada Standar Operasional Prosedurnya yang harus diikuti. Bedasarkan hasil wawancara yang dilakukan kepada informan menunjukan bahwa standar input dalam pelaksanaan pelayanan PMTCT di Rumah Sakit Umum Pusat H. Adam Malik sudah dalam kategori baik. berdasarkan Sumber Daya Mansia (SDM) sudah mencukupi dan memiliki pendidikan sesuai kompitensi profesinya masing-masing serta telah mendapatkan pelatihan. Berdasarkan fasilitas dan peralatan sudah baik hal ini dilihat dari adanya fasilitas laboratorium yang sudah mendukung dan peralatan yang digunakan sudah sesuai dengan ketentuan yang berlaku.

\section{Standar Proses}


Journal of Healthcare Technology and Medicine Vol. 6 No. 2 Oktober 2020

Universitas Ubudiyah Indonesia

e-ISSN : 2615-109X

Wawancara untuk mendapatkan informai seputar pelaksanaan pelayanan PMTCT dilakukan kepada informan baik yang sebagai petugas kesehatan maupun ibu hamil. Dari jawaban mereka terdapat persamaan persepsi bahwa pelaksanaan pelayanan PMTCT sudah dilakukan dengan baik dan sesuai ketentuan yang berlaku. Jawaban informan ibu hamil mengatakan bahwa mereka sangat senang dengan pelayanan yang diterimanya. Mereka menjelaskan petugas kesehatan dalam memberikan pelayanan sudah sangat baik. Mereka menilai petugas sangat ramah, sopan santu, serta terbuka dalam menjelasakan dan memberi penjelasana seputar penyakit HIV kepada mereka.

Sementara itu informan dari petugas kesehatan menjelaskan mereka sudah berusaha melakukan dan memberikan pelayanan sebaik dan semaksiaml mungkin dan mereka menegaskan sudah memberikan pelayanan yang baik, pelayanan yang berkualitas sesuai prosedur dan standar yang telah ditentukan. dan mereka berharap kepada semua pasien yang mendapatkan asuhan agar mereka puas dan senang dengan pelayanan yang mereka berikan.

Dari jawaban informan antara pasien dan petugas terdapat kesamaan persepsi, yaitu psien mengatakan bahwa pelaksanaan pelayanannya sudah baik, serta semua petugas melakukan dan memeberikan pelayanan dengan sopan dan ramah. Sementara itu, petugas mengatakan mereka sudah memberikan pelayanan yang baik kepada setiap pasien yaitu dengan melakukan anamneses yang secara lengkap, pemeriksaan fisik secara lengkap, pemeriksaan laboratorium dan memberikan konseling kepada pasien yang positife HIV.

Dari jawaban-jawaban yang didpatkan dari semua informan peneliti mengatakan bahwa dalam pelaksanaannya pelayanan PMTCT pada ibu hamil sudah dilakukan dengan baik. Jawaban yang didapatkan dari keempat informan adalah sebagai berikut. Informan pertama menjelaskan bahwa informan sudah pernah mengikuti pelatihan untuk program PMCT. Informan selanjutnya memberikan jawban bahwa karena dia berlatar belakang Bidan makanya dia tidak pernah mengikuti dan mendapatkan pelatihan secara spesiFik tentang PMTCT namun informan menegaskan kalau pelatihan sesuai bidangnya yaitu kebidanan pernah mengikuti pelatihan.Dua informan yang lainnya juga memberikan penjelasan yang sama. Bahwa informan belum pernah mengikuti atau mendapatkan pelatihan secara spesifik mengenai PMTCT. Berdasarkan jawaban dari ke empat informan maka peneliti menyimpulkan bahwa diantara semua petugas kesehatan hanya 1 orang petugas yang mendapat penelitian tentang PMTCT yang selebihnya hanya mengikuti pelatihan untuk pelayanan kebidanan dan kandungan. 
Journal of Healthcare Technology and Medicine Vol. 6 No. 2 Oktober 2020

Universitas Ubudiyah Indonesia

e-ISSN : 2615-109X

Wawancara untuk mendapatkan informasi seputar sosialisasi program PMTCT dilakukan kepada ibu hamil dan petugas kesehatan. Antara jawaban petugas kesehatan dan ibu hamil terdapat kesamaan. yaitu semua informan mengatakan bahwa dalam hal sosialisasi program PMTCT tidak ada dilakukannya penyuluhan kepada pasien. Berikut adalah jawaban yang diperoleh dari informan ibu hamil. Informan mengaatakan dalam menerima asuhan yang diberikan oleh petugas kesehatan. Mereka diberikan penjelasan secara rinci tentang penyakit mereka, namun mereka tidak pernah diberikan penyuluhan oleh petugas kesehatan melainkan hanya diberikan penjelasan secara individu.

Jawaban yang sama juga diberikan oleh informan petugas kesehatan. Semua informan menjelaskan bahwa dalam segi sosialisasi program memang belum ada dilakukannya penyuluhan kepada pasien melainkan hanya memberikan penjelasan semacam pendidikan kesehatan saja. Informan juga menjelaskan pasien diberikan informasi seputar program PMTCT dengan cara memberikan brosur dan pamlet kepada pasien sambal dijelaskan oleh Dokter magang yang sedang menjalani tugas magang di Poli Ibu Hamil.

Bedasarkan hasil wawncara yang dilakukan pada informan dapat dikatakan bahwa standar proses dalam pelaksanaan pelayanan PMTCT pada ANC sudah dikategorikan sudah baik. Hal ini dapat dilihat dari pelaksanaan pelayanan yang sudah dilakukan dengan baik dan sesuai standar yang ditentukan dan petugas yang memberikan pelayanan sudah mendapatkan pelatihan sebelumnya. Hal ini sejalan dengan penelitian Mujayanah (2011) yang menyatakan bahwa peran petugas kesehatan sangat mempengaruhi keberhasilan dalam suatu pelayanan kesehatan. Namun, dalam hal sosialisasi program perlu ditingkatkan lagi. Hal ini, bertujuan agar masyarakat atau pasien menjadi lebih faham dengan pelayanan PMTCT dan tentang HIV.

\section{Standar Output}

Dari jawaban beberapa informan diatas menunjukkan bahwa pasien merasa puas dengan pelayanan yang mereka terima. Informan mengatakan bahwa pelayanan di PIH dan Pusyansus sudah bagus dan baik. Dari hasil wawancara yang dilakukan terhadap delapan orang informan yaitu ibu hamil yang dinyatakan positive HIV dan menerima pelayanan PMTCT di Rumah Sakit Umum Pusat H. Adam Malik Pusat Kota Medan mereka memberikan jawaban yang senada sebagai berikut. Informan pertama mengatakan bahwa dia selalu datang melakukan pemeriksaan ke PIH sesuai jadwal yang diberikan oleh Dokter dan informan juga memaparkan bahwa informan selalu mengkonsumsi obat yang sudah diberikan 
Journal of Healthcare Technology and Medicine Vol. 6 No. 2 Oktober 2020

Universitas Ubudiyah Indonesia

e-ISSN : 2615-109X

petugas kesehatan sesuai jadwal dan teratur. Informan berikutny juga memberikan jawaban yang sama dengan mengatakan selalu datang ke PIH untuk melakukan pemeriksaan sesuai jadwal dan selalu teratur untuk mengkonsumsi obat yang diterimanya dari petugas kesehatan.

Jawaban yang serupa juga diberikan oleh dua informan yang lain. Mereka menjelaskan bahwa selalu berkunjung ke PIH dan Pusyansus untuk memeriksakan diri mereka sesuai jadwal. Tetapi mereka mengaku pernah sekali tidak datang pemeriksaan dikarenakan karena disebabkan ketidak tahuannya, dan pasien berikutnya menjelaskan alasan dia tidak datang pemeriksaan lantaran dikarenakan tidak adanya keluhan bearti yang dia rasakan. Namun meski demikian kedua informan tersebut mengaku selalu mengkonsumsi obat mereka sesuai yang di anjurkan Dokter. Jawaban yang sama juga diberikan oleh informan berikutnya. Informan menjelaskan bahwa selain datang melakukan pemeriksaan sesuai jadwal dari Dokter mereka akan datang melakukan kunjungan apabila merasakan keluhan seperti sakit pinggang. Hal ini bertujuan untuk mencegah agar tidak terjadi hal-hal yang tidak diinginkan kepada janin dan diri informan sendiri.

Berdasarkan jawaban informan tersebut diatas bahwa semua informan sudah patuh untuk melakukan kunjungan sesuai dengan jadwal yang diberikan petugas dan selalu meminum obat mereka dengan teratur.

Hasil wawancara yang dilakukan terhadap informan untuk melihat utilisasi program PMTCT adalah sebagai berikut. Dari pertanyaan yang diajukan terhadap 4 orang informan mereka memberikan jawaban yang sama. Berikut jawaban yang diberikan informan pertama. Informan menjelaskan pemanfaatakan atau utilisasi program PMTCT sudah mengalami peningkatan hal ini dapat dilihat dari adanya peningkatan jumlah pasien yang datang untuk berobat di klinik PIH dan Pusyansus.

Jawaban senada juga dituturkan oleh informan yang lainnya. Informan menjelaskan bahwa jumlah pasien ibu hamil yang datang untuk pemeriksaan mengalami peningkatan hal ini dapat dilihat dari kunjungan yang mereka lakukan. Informan menjelaskan hal ini tentu saja karena pasien merasakan manfaat yang bearti dalam pelayanan PMTCT sehingga mereka rutin dan datang untuk melakukan pemeriksaan. Dari hasil wawancara dari informan, dapat dikatakan bahwa standar output dalam pelaksanaan pelayanan PMTCT pada ANC di Rumah Sakit Umum Pusat H. Adam Malik sudah baik hal ini dapat dilihat dari hasil penelitian yang menunjukan adanya pengingkatan kepuasan dan kepatuhan pasien. Pasien mengaku sangat puas dengan pelayanan yang diberikan petugas kesehatan. Selain itu, hal 
Journal of Healthcare Technology and Medicine Vol. 6 No. 2 Oktober 2020

Universitas Ubudiyah Indonesia

e-ISSN : 2615-109X

yang menunjukan adalah terdapat peningkatan pemanfaatan pelayanan PMTCT hal ini ditandai dengan semakin meningkatnya jumlah pasien ibu hamil yang diberikan pelayanan PMTCT oleh petugas kesehatan.

\section{KESIMPULAN}

Kesimpulan yang didapatkan dari penelitian ini adalah bahwa pelaksanaan pelayanan PMTCT pada $A N C$ di Rumah Sakit Umum Pusat H. Adam Malik sudah baik dan diharapkan melakukan peningkatan dalam sosialisasi program terhadap pasien HIV.

\section{DAFTAR PUSTAKA}

Afiyanti, Yanti dan Nur Rahchmawati, Imami. (2014). Metodologi Penelitian Kualitatif dalam Riset Keperawatan. Rajawali Pers: Jakarta.

Arikunto, Suharsimi dan Abdul Jabar, Safruddin. (2009). Evaluasi Program Pendidikan. Bumi Aksara: Jakarta.

Depkes RI. (2008). Modul Pelatihan Pencegahan Penularan HIV dari Ibu ke Bayi Prevention of Mother To Child HIV Transmission, Jakarta

Direktur Jenderal Bina Gizi dan KIA. (2012). Integritas Program PPIA (PMTCT) di Pelayanan Kesehatan Ibu dan Anak. Disampaikan pada Lecture Series Pusat Penelitian HIV/AIDS UNIKA ATMAJAYA Peranan Bidan Dalam Mendukung Pencegahan Penularan HIV dari Ibu Ke Bayi. Jakrta: Direktur Jenderal Bina Gizi dan KIA.

E. Widiyasari, Z. Shaluhiyah, and A.Margawati. (2016). Implememntation of Integration between Prevention of Mother to Child HIV Transmission (PMTCT) and Antenatal Services at Primary Healthcare Centers of Surabaya. Jurnal Manajemen Kesehatan Indonesia, vol. 2, no. 1, Feb. 2016. https://doi.org/10.14710/jmki.2.1.2014.\%p

Herman Sofyandi. (2008). Manajemen Sumber Daya Manusia, Edisi Pertama, Penerbit Graha Ilmu, Yogyakarta.

Inka Kartika Ningsih, Sari Hastuti. (2018). Kajian Pencegahan Penularan HIV dari Ibu ke Anak pada Antenatal Care oleh Bidan Praktik Mandiri di Yogyakarta. Jurnal Administrasi Kesehatan Indonesia Volume 6 Nomor 1 Januari - Juni 2018

Kebijakan AIDS Indonesia.(2015). Berita Media Dalam situs: http://www.kebijakanaidsindonesia.net. 
Journal of Healthcare Technology and Medicine Vol. 6 No. 2 Oktober 2020

Universitas Ubudiyah Indonesia

e-ISSN : 2615-109X

Kemenkes RI. (2009). Pedoman Nasional Monitoring Dan Evaluasi Program Pengendalian HIV/AIDS. Kementerian Kesehatan RI: Jakarta.

Kemenkes RI. (2012). Pedoman Nasional Pencegahan Penularan HIV Dari Ibu Ke Anak (PPIA). Kementerian Kesehatan: Jakarta.

Kemenkes RI. (2013). Rencana Aksi Nasional Pencegahan Penularan HIV Dari Ibu Ke Anak (PPIA). Kementerian Kesehatan RI: Jakarta.

Kemenkes RI (2014). Pedoman Penerapan Terapi HIV Pada Anak. Kementerian Kesehatan RI: Jakarta.

Kozier. Erb, Berman. Snyder. (2010). Buku Ajar Fondamental Keperawatan:Konsep, Proses \& Praktik, Volume: 1, Edisi : 7, EGC : Jakarta

Marya Yenita Sitohang, 2017. Utilization Factors of Prevention Mother to Child HIV Transmission (PMTCT) Program Among Pregnant Women. Journal of Indonesian social science and humanities. Vol 7, No 2,2017

Maryunani, Anik dan Aeman, Ummu, 2009. Buku Saku Pencegahan Penularan HIV Dari Ibu Ke Bayi. Trans Info Media: Jakarta.

Mujayanah, U, Mifbakhuddin, dan Kusumawati, E. (2011). Hubungan Antara Pengetahuan dengan Sikap Ibu Hamil Pada Program Antenatal Care Integrasi Terhadap Prevention Of Mother to Child HIV Transmission (PMTCT). Universitas Muhammadiyah Semarang.

Nur'ainun Jambak, Aria Wahyuni.(2018). Faktor-faktor yang mempengaruhi Perubahan Perilaku Risiko HIV/ AIDS. Jurnal Muitara Ners vol 1.no1 2018. http://Ic-jurnalsarimutiara.ac.id/index-php/NERS .Pubilshed 2018-01-15.

Permenkes RI No 51 Th. 2013. (2013) Pedoman Pencegahan Penularan Hiv Dari Ibu Ke Anak. Menkes RI: Jakarta.

Putri Yuriati. (2016). Evaluasi Pelaksanaan Kegiatan Prevention of Mother to Child Transmission (PMTC) pada Ibu Hamil di Kota Tanjung Pinang. Public Health Perspective Journal. Volume 1 no 1 tahun 2016

Purwoastuti, Endang dan Walyani, Elisabeth. (2015). Mutu Pelayanan Kesehatan dan Kebidanan. Pustaka Baru Press: Yogyakarta

Riska Susanti Pasaribu. (2019). Faktor-faktor yang berhubungan dengan Kejadian HIV pada WPS (Wanita Pekerja Seks( di Klinik VCT (Voluntary Conseling and Testing) Wilayah 
Journal of Healthcare Technology and Medicine Vol. 6 No. 2 Oktober 2020

Universitas Ubudiyah Indonesia

e-ISSN : 2615-109X

Kerja Puskesmas Padang Bulan Kota Medan. Jurnal Muitara Ners vol: 2. no: 1 tahun 2019. http://Ic-jurnalsari-mutiara.ac.id/index-php/NERS .Pubilshed 2019-01-23.

Sugiyono. (2012). Metode Penelitian Kuantitatif Kualitatif dan R\&D. Alfabeta: CV. Bandung.

Syarah, Vonny. (2013). Perilaku Bidan Kia/Kb Dalam Pelaksanaan Program Prevention Of Mother To Child Transmission (Pmtct) Di Rumah Sakit Haji Kota Medan. Skripsi Fakultas Kesehatan Masyarakat Universitas Sumatera Utara.

USAID Indonesia. (2015). Policy Paper Rencana Aksi Daerah Percepatan Penurunan Angka Kematian Ibu (RAD PPAKI). USAID Kinerja

WidayantiL. P. (2020). Evaluasi PMTCT (Prevention Mother To Child Transmission) pada IRT dengan HIV di Jatim. Journal of Health Science and Prevention, 4(1), 32-41. https://doi.org/10.29080/jhsp.v4i1.310 